\begin{tabular}{cc|c}
\hline Tar. Bil. Der. & Tarım Bilimleri Dergisi & Journal of Agricultural Sciences \\
& $\begin{array}{c}\text { Dergi web sayfası: } \\
\text { www.agri.ankara.edu.tr/dergi }\end{array}$ & Journal homepage: \\
& www.agri.ankara.edu.tr/journal
\end{tabular}

\title{
Compost Effects on Soil Nutritional Quality and Pepper (Capsicum annuum L.) Yield
}

\author{
Melis ÇERÇİĞLU ${ }^{\mathbf{a}}$ \\ ${ }^{a}$ Department of Laboratory Technology, Vocational College of Simav, Kutahya Dumlupinar University, Simav, Kutahya, 43500, \\ TURKEY
}

\author{
ARTICLE INFO \\ Research Article \\ DOI: 10.15832 /ankutbd.396547 \\ Corresponding Author: Melis ÇERÇİĞLU, E-mail: melis.cercioglu@dpu.edu.tr, Tel: +90 (274) 44343 43/6525 \\ Received: 12 February 2018, Received in Revised Form: 05 April 2018, Accepted: 17 April 2018
}

\begin{abstract}
There is a large amount of organic waste depending on the climatic conditions and product diversity in the agricultural areas of Turkey. These wastes can be used as a soil conditioner to reduce environmental problems and enrich soil organic matter by the transformation of organic wastes into organic manure with the process of composting. This study was performed to investigate the effects of composted greenhouse wastes (tomato residues) and animal manure on macro nutrient contents of soil and green pepper yield. Treatments were as follows: (1) Control, (2) mineral fertilizer, (3) 40 $\mathrm{t} \mathrm{ha}^{-1}$ animal manure, (4) $40 \mathrm{t} \mathrm{ha}^{-1}$ animal manure + mineral fertilizer, (5) $40 \mathrm{t} \mathrm{ha}^{-1}$ tomato residuals (6) $40 \mathrm{t} \mathrm{ha}^{-1}$ tomato residuals + mineral fertilizer, (7) $80 \mathrm{t} \mathrm{ha}^{-1}$ tomato residuals, (8) $80 \mathrm{t} \mathrm{ha}^{-1}$ tomato residuals + mineral fertilizer. Three replicates each of disturbed soil samples (two sampling) were collected $(0-20 \mathrm{~cm})$ from each treatment in two vegetation period and green pepper was used as a test plant in the study. In consequence of the research, significant increases were observed in crop yield and macro nutrient contents of soil. The highest increasing rate was analyzed in yield values as $305 \%$. The most effective treatments on soil macro nutrient content and yield were determined as $40 \mathrm{tha}^{-1}$ animal manure combined with mineral fertilizer and $80 \mathrm{tha}^{-1}$ composted tomato residues combined with mineral fertilizer.
\end{abstract}

Keywords: Animal manure; Compost; Greenhouse wastes; Macro nutrients; Yield

(C) Ankara Üniversitesi Ziraat Fakültesi

\section{Introduction}

Conventional agricultural practices may include frequent and intensive tillage and the extensive use of fertilizers and pesticides. Such practices can result in a loss of organic matter (OM), leading to the degradation of cultivated soils and a decline in soil quality (Lal 2007; Peigne et al 2007; BatlleBayer et al 2010; Pan et al 2010). An integrated use of inorganic fertilizer with organic manure is a sustainable approach for efficient nutrient usage which enhances efficiency of the chemical fertilizers while reducing nutrient losses (Schoebitz \& Vidal 2016).

Organic wastes such as animal manures, byproducts of several kinds and composted residues can be used as amendments to increase soil fertility. They are important sources for enriching plant development and soil quality (Alluvione et al 2013; Li \& Han 2016). Composting of the plant residuals and unusable organic wastes is an old and inexpensive method; the so-obtained compost can be used as an organic fertilizer or soil amendment 
(Chang et al 2006). Applications of plant residues, cotton gin, composted urban waste, and poultry manure within high organic matter content to soils have been used to restore and maintain soil of organic matter, thus reclaiming degraded soils and supplying plant nutrients (Ros et al 2003; Walker 2003; Tejeda et al 2006).

Tomato (Solanum lycopersicum L.) is the most commonly grown vegetable plant in greenhouses and represented $55 \%$ of total vegetable production in Turkey. Greenhouse tomato production was determined as $458.6 \mathrm{t} \mathrm{ha}^{-1}$ in Turkey and $100 \mathrm{t} \mathrm{ha}^{-1}$ in Simav district of Kutahya in 2016 (TUIK 2017). Although production wastes or residues of tomato, their high organic matter content, are appropriate for composting, they are burned or dumped in open areas in Turkey (Kulcu 2014). Even though there are many studies about agricultural wastes, there is no sample research to solve waste disposal problems for farmers in Simav which is suitable for intensive greenhouse production. The aim of this study to evaluate these wastes as an alternative source due to the fact that composting of these wastes prevents environmental pollution and diseases and pests.

Green pepper was used as a test plant in the study. Pepper plant in our country, many arid and semi-arid areas where salinity problem commonly seen as a potential risk for croplands is one of the most important grown vegetable in greenhouses and fields. Current status of pepper plant production under greenhouses in Turkey was found as 307.2 $\mathrm{t} \mathrm{ha}^{-1}$. Total greenhouse area in Simav district was 426.1 ha and pepper production in greenhouses was $50 \mathrm{t} \mathrm{ha}^{-1}$ (TUIK 2017).

In this study, the effects of composted tomato plant residues and animal manure on macro nutrient composition of soil and pepper yield were compared.

\section{Material and Methods}

\subsection{Site description and treatments}

This study was conducted in the greenhouses of Vocational College of Simav, Dumlupinar University in Simav, Kutahya, Turkey (Figure 1).
The experiment soil was classified as sandy loam with slightly alkaline reaction and some physicochemical properties were given in Table 1. The experiment was established in a randomized block design with three replications. The plot size was $3 \mathrm{~m} \times 2 \mathrm{~m}$ with each plot having $80 \mathrm{~cm}$ and $80 \mathrm{~cm}$ distance between and within rows, respectively with 13330 plants $\mathrm{ha}^{-1}$ plant population. Monoammonium phosphate $(12 \% \mathrm{~N}, 61 \% \mathrm{P})$, potassium sulfate $(50 \% \mathrm{~K})$, ammonium nitrate $(33 \% \mathrm{~N})$, potassium nitrate $(13 \% \mathrm{~N}, 46 \% \mathrm{~K})$, and calcium

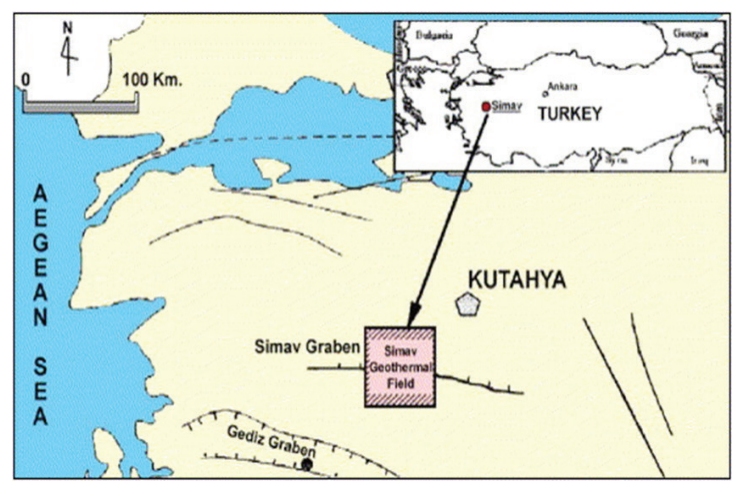

Figure 1- Location of the study area

Table 1- Some physical andchemical properties of experimental soil (Cercioglu et al 2017)

\begin{tabular}{lr}
\hline Soil texture & Sandy loam \\
\hline Sand $(\%)$ & 60.48 \\
Silt $(\%)$ & 27.64 \\
Clay $(\%)$ & 10.88 \\
$\mathrm{CaCO}_{3}(\%)$ & 1.80 \\
$\mathrm{OM}(\%)$ & 1.85 \\
Total N $(\%)$ & 0.17 \\
$\mathrm{pH}$ & 7.71 \\
$\mathrm{EC}\left(\mu \mathrm{S} \mathrm{cm}^{-1}\right)$ & 1467.00 \\
$\mathrm{P}\left(\mathrm{mg} \mathrm{kg}^{-1}\right)$ & 104.60 \\
$\mathrm{~K}\left(\mathrm{mg} \mathrm{kg}^{-1}\right)$ & 206.00 \\
$\mathrm{Ca}\left(\mathrm{mg} \mathrm{kg}^{-1}\right)$ & 3760.00 \\
$\mathrm{Mg}\left(\mathrm{mg} \mathrm{kg}^{-1}\right)$ & 843.00 \\
$\mathrm{Na}\left(\mathrm{mg} \mathrm{kg}^{-1}\right)$ & 213.30 \\
$\mathrm{Fe}\left(\mathrm{mg} \mathrm{kg}^{-1}\right)$ & 7.98 \\
$\mathrm{Cu}\left(\mathrm{mg} \mathrm{kg}^{-1}\right)$ & 2.15 \\
$\mathrm{Zn}\left(\mathrm{mg} \mathrm{kg}^{-1}\right)$ & 3.92 \\
$\mathrm{Mn}\left(\mathrm{mg} \mathrm{kg}^{-1}\right)$ & 10.10 \\
\hline
\end{tabular}


nitrate $(15.5 \% \mathrm{~N}, 26.5 \% \mathrm{CaO})$ were used as mineral fertilizers (NPK) and applied to the plots in the first hoe period after one month of planting. Animal manure (AM), and tomato residues (TR) were used as organic fertilizers and applied to the plots one day before planting.

Pepper (Capsicum annuum L.) is grown as an annual plant and is actually herbaceous perennial that's survives and yield for several years in tropical climates (Kelley \& Boyhan 2009). The material used for composting was tomato residue obtained from the greenhouses located in Simav, Kutahya. Composting was performed outdoor under a roof. The moisture content of the compost was analyzed approximately $55 \%$ by weighing the material regularly and adding water when necessary. The aeration was made by manual turning during the composting process. The composting process lasted 3 months and composting was considered complete when the $\mathrm{C}: \mathrm{N}$ ratio $(7.99)$ and temperature $\left(35^{\circ} \mathrm{C}\right)$ became constant. Composted tomato residues and animal manure obtained from farmers were added to the soil after composting. All doses of organic wastes were determined according to initial soil analysis results, and nutrient removal by pepper plant from soil. Some properties of these organic wastes were reported in Table 2. The treatments where: (1) Control, (2) NPK, (3) $40 \mathrm{t} \mathrm{ha}^{-1} \mathrm{AM}$, (4) $40 \mathrm{t} \mathrm{ha}^{-1} \mathrm{AM}+\mathrm{NPK}$, (5) $40 \mathrm{t} \mathrm{ha}^{-1} \mathrm{TR}$ (6) $40 \mathrm{t} \mathrm{ha}^{-1}$ TR + NPK, (7) $80 \mathrm{t} \mathrm{ha}^{-1} \mathrm{TR},(8) 80 \mathrm{tha}^{-1} \mathrm{TR}+\mathrm{NPK}$.

\subsection{Sampling and laboratory analyses}

During the experiment, two soil samples were taken from $0-20 \mathrm{~cm}$ depth for each vegetation (first vegetation: November, 2014 and March, 2015; second vegetation: April, 2015 and August, 2015). The samples were air-dried and sieved through $2 \mathrm{~mm}$ sieve. Soil texture was determined according to Bouyoucos (1962). Soil organic matter was determined according to method of Nelson \& Sommer (1982). Soil reaction $(\mathrm{pH})$ in $1: 1(\mathrm{w} / \mathrm{v})$ soil water suspension by $\mathrm{pH}$ meter; and electrical conductivity (EC) in the same suspension by EC meter (Kacar 1994). Calcium carbonate was measured according to Scheibler
Table 2-Some chemical properties of organic wastes (Cercioglu et al 2017)

\begin{tabular}{lrr}
\hline Parameters & $\begin{array}{r}\text { Composted } \\
\text { tomato } \\
\text { residuals }\end{array}$ & $\begin{array}{r}\text { Animal } \\
\text { manure }\end{array}$ \\
\hline $\mathrm{pH}$ & 8.79 & 8.43 \\
$\mathrm{EC}\left(\mu \mathrm{S} \mathrm{cm}{ }^{-1}\right)$ & 1772.00 & 2700.00 \\
$\mathrm{OM}(\%)$ & 30.00 & 57.80 \\
$\mathrm{C}: \mathrm{N}$ & 7.99 .00 & 14.20 \\
Total N $(\%)$ & 2.18 & 2.35 \\
Total $\mathrm{P}\left(\mathrm{mg} \mathrm{kg}{ }^{-1}\right)$ & 1284.00 & 3600.00 \\
Total K $\left(\mathrm{mg} \mathrm{kg}^{-1}\right)$ & 5547.00 & 9400.00 \\
Total Ca $\left(\mathrm{mg} \mathrm{kg}^{-1}\right)$ & 11540.00 & 24200.00 \\
Total $\mathrm{Mg}\left(\mathrm{mg} \mathrm{kg}^{-1}\right)$ & 2469.00 & 5300.00 \\
Total $\mathrm{Na}\left(\mathrm{mg} \mathrm{kg}^{-1}\right)$ & 481.20 & 588.00 \\
Total Fe $\left(\mathrm{mg} \mathrm{kg}^{-1}\right)$ & 5964.00 & 784.00 \\
Total $\mathrm{Mn}\left(\mathrm{mg} \mathrm{kg}^{-1}\right)$ & 254.00 & 202.00 \\
Total Cu $\left(\mathrm{mg} \mathrm{kg}^{-1}\right)$ & 10.60 & 12.30 \\
Total $\mathrm{Zn}\left(\mathrm{mg} \mathrm{kg}^{-1}\right)$ & 45.50 & 51.60 \\
\hline
\end{tabular}

method (Schlichting \& Blume 1966). Total N was analysed according to Kjeldahl method (Bremner 1965). Available $P$ was determined by the Mo blue method in a $\mathrm{NaHCO}_{3}$ extract (Olsen et al 1954). Available $\mathrm{K}, \mathrm{Ca}, \mathrm{Mg}$ and $\mathrm{Na}$ were determined by 1 $\mathrm{N} \mathrm{NH}_{4} \mathrm{OAc}(\mathrm{pH}: 7)$ method. Samples of composted materials were collected from the bulks separately, and air-dried. The $\mathrm{pH}$ and $\mathrm{EC}$ values of composted materials were analyzed in aqueous extract, which was obtained mechanically shaking the samples for 1 hour with distilled water at a solid/water ratio of 1:10 (dry weight/volume) by using $\mathrm{pH}$ and EC meter, respectively (Kacar 1994). Moreover, organic matter (Nelson \& Sommer 1982); total N (Bremner 1965); available $\mathrm{P}$ (Olsen et al 1954); available K, $\mathrm{Ca}, \mathrm{Na}, \mathrm{Mg}$ contents (Pratt 1965); and available micro nutrient contents (Lindsay \& Norvell 1978) were determined.

Drip irrigation method was used according to water needs of plant in the study. Pepper plants harvested from each plot were weighed after each harvest and determined their moist weights. After these procedures, all yield values were calculated from plot area as $\mathrm{tha}^{-1}$. 


\subsection{Statistical analysis}

Analysis of variance (ANOVA) and Duncan's tests were conducted with a $\mathrm{P}<0.05$ significance level and $95 \%$ confidence interval using SPSS Version 25 (IBM Corp. 2017) statistical software.

\section{Results and Discussion}

\subsection{Macro nutrient contents of soil}

Soil macro nutrients (N, P, K, Ca, Na, Mg) were presented in Table 3. Total $\mathrm{N}$ content of soil increased in all the treatments compared to control plots. At the beginning of the experiment, total $\mathrm{N}$ was analyzed as $0.17 \%$. With the application of wastes, $\mathrm{N}$ amounts varied between 0.11 to $0.37 \%$ during first and second vegetation periods. These values were found sufficent when compared with the limit values of soil nitrogen according to Sillanpää (1990). Compared with the control, the highest total $\mathrm{N}$ content of soil was obtained as $0.37 \%$ in the $40 \mathrm{tha}^{-1} \mathrm{AM}+\mathrm{NPK}$ and 80 $\mathrm{t} \mathrm{ha}^{-1} \mathrm{TR}+\mathrm{NPK}$ plots, an increase of $117 \%$ in the first soil samples of first vegetation. It was closely related to the high nitrogen content of animal manure $(2.35 \%)$ and composted tomato residues $(2.18 \%)$ applied to the soil. Statistically, there was no significant differences among both treatments $\left(40 \mathrm{t} \mathrm{ha}^{-1} \mathrm{AM}+\right.$ NPK and $80 \mathrm{tha}^{-1} \mathrm{TR}+\mathrm{NPK}$ ) in terms of $\mathrm{N}$ contents of the first soil samples of first vegetation. Similar results were reported by Wang et al (2004) in plots treated with composted dairy and swine manures. According to Ayuso et al (1996), the increase may be attributed to a direct effect of organic $\mathrm{N}$ derived from the compost, which is slowly mineralized in soil after the composting process (Castellanos \& Pratt 1981). Available P content of soil was increased by all the treatments. During all vegetation periods, soil $\mathrm{P}$ contents varied between 60.90 to $136.10 \mathrm{mg} \mathrm{kg}^{-1}$ with application of these materials. The highest available $\mathrm{P}$ content in soils was analysed as $136.10 \mathrm{mg} \mathrm{kg}^{-1}$ in the first soil samples of first vegetation under $40 \mathrm{t}$ $\mathrm{ha}^{-1} \mathrm{AM}+\mathrm{NPK}$ plot. The increasing rate was $30.1 \%$ compared to the control $\left(104.60 \mathrm{mg} \mathrm{kg}^{-1}\right)$. Available soil $\mathrm{P}$ was found in very high level $\left(>80 \mathrm{mg} \mathrm{kg}^{-1}\right)$ according to Sillanpää (1990). These results were found similar to the other study about greenhouse soils (Kaplan et al 1995). Moreover, it was closely related to the high phosphorus contents of composted tomato residues (1284 mg kg-1) and animal manure (3600 mg kg-1) applied to the soil. The increase in the available forms of phosphorus and sulfur has explained by increase of soil organic matter content (Shang et al 2014; Siwik-Ziomek \& Lemanowicz 2014). Before the applications of the materials, soil initial available $\mathrm{K}$ content was determined as 206 $\mathrm{mg} \mathrm{kg}{ }^{-1}$ and total $\mathrm{K}$ content of animal manure and composted tomato residues were $9400 \mathrm{mg} \mathrm{kg}^{-1}$ and $5547 \mathrm{mg} \mathrm{kg}^{-1}$, respectively. Available K content of soil was significantly affected with all the treatments. The maximum $\mathrm{K}$ contents were measured as 503.30 $\mathrm{mg} \mathrm{kg}{ }^{-1}$, an increase of $144 \%$ when compared to the control by the application of $40 \mathrm{t} \mathrm{ha}^{-1} \mathrm{AM}+\mathrm{NPK}$ in the first soil samples of first vegetation (Table 3). Similar to N content of soil, both treatments (40 t ha ${ }^{-1} \mathrm{AM}+\mathrm{NPK}$ and $\left.80 \mathrm{t} \mathrm{ha}^{-1} \mathrm{TR}+\mathrm{NPK}\right)$ showed statistically same significance level. According to Sumner \& Miller (1996), available K values were varied from sufficient level (140-370 $\left.\mathrm{mg} \mathrm{kg}^{-1}\right)$ to high level (370-1000 $\mathrm{mg} \mathrm{kg}^{-1}$ ) after material applications. An increase in the exchangeable potassium content of soil was also observed by Zhang et al (2011) after application of NPK and manure (pig, horse, cattle or sheep). Saltalı et al (2000) found that increasing rate of tobacco waste increased total $\mathrm{N}$ and available $\mathrm{P}$, $\mathrm{K}$ contents. Obtained data showed that application of animal manure and plant residuals to alkaline soils improved both soil conditions and nutrient concentration of soil to increased sufficient crop production. Some authors have also found an increase in $\mathrm{K}$ and $\mathrm{Mg}$ in the soil after organic amendments (Bulluck et al 2002; Edmeades 2003). They attributed the result to the high nutrient contents of the compost and the increase of cation exchange capacity due to organic matter added. While the available Ca content of soil was found higher in second vegetation soil, the available $\mathrm{Na}$ and $\mathrm{Mg}$ content of soil was higher in first vegetation soil. Soils treated $80 \mathrm{t} \mathrm{ha}^{-1} \mathrm{TR}+\mathrm{NPK}$ had the highest available Ca content (4397 $\left.\mathrm{mg} \mathrm{kg}^{-1}\right)$ with an increase of $114 \%$ over the control. Soil available $\mathrm{Ca}$ values were analyzed in a high level (3500-10000 $\mathrm{mg} \mathrm{kg}{ }^{-1}$ ) as compared to the limit values of Sumner \& Miller (1996). As shown in Table 3, the highest Na content was determined as $149.50 \mathrm{mg} \mathrm{kg}^{-1}$ in $80 \mathrm{t} \mathrm{ha}^{-1}$ TR + NPK application in the first vegetation soil and 


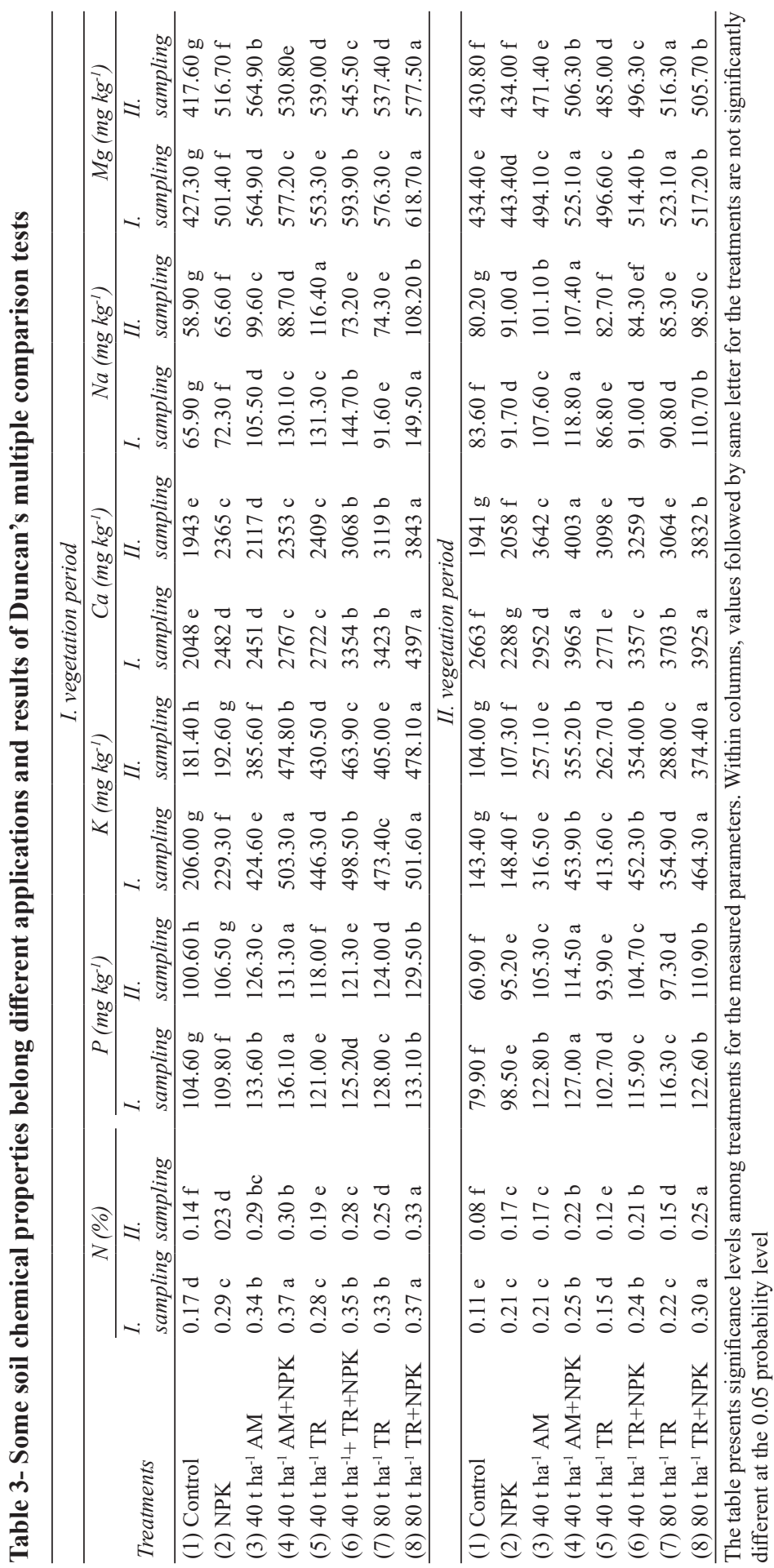


as $118.80 \mathrm{mg} \mathrm{kg}^{-1}$ in $40 \mathrm{t} \mathrm{ha}^{-1} \mathrm{AM}+\mathrm{NPK}$ application in the second vegetation soil. Available $\mathrm{Na}$ values were found in sufficient level $\left(68-230 \mathrm{mg} \mathrm{kg}^{-1}\right)$ according to Loue' (1968). The highest Mg contents was as $618.70 \mathrm{mg} \mathrm{kg}^{-1}$ in first vegetation soils with 80 $\mathrm{t} \mathrm{ha}^{-1}$ TR + NPK whereas, the highest in the second vegetation period with $40 \mathrm{t} \mathrm{ha}^{-1} \mathrm{AM}+\mathrm{NPK}$ (525.10 $\left.\mathrm{mg} \mathrm{kg}{ }^{-1}\right)$ and $80 \mathrm{t} \mathrm{ha}^{-1} \mathrm{TR}\left(523.10 \mathrm{mg} \mathrm{kg}^{-1}\right)$. Available $\mathrm{Mg}$ contents of soil were varied between $417.60 \mathrm{mg}$ $\mathrm{kg}^{-1}$ (sufficient level: $160-480 \mathrm{mg} \mathrm{kg}^{-1}$ ) and 618.70 mg kg-1 (high level: 480-1500 mg kg-1) (Sumner \& Miller 1996). Similarly, Agbede \& Ojeniyi (2009) determined that application of poultry manure to any tillage treatment improved soil total $\mathrm{N}$, available $\mathrm{P}$, exchangeable $\mathrm{K}, \mathrm{Ca}$ and $\mathrm{Mg}$ concentrations and grain yield of sorghum. Courtney \& Mullen (2008) also obtained that available nutritional elements such as potassium $(\mathrm{K})$, calcium $(\mathrm{Ca})$, magnesium $(\mathrm{Mg})$, and phosphorus $(\mathrm{P})$ increased when compost was applied.

\subsection{Pepper yield}

All the organic wastes added to the soil significantly $(\mathrm{P}<0.05)$ enhanced pepper yield compared to the control soil. The greatest yield values were $13.10 \mathrm{t}$ $\mathrm{ha}^{-1}$ and $15.46 \mathrm{tha}^{-1}$ in the first and second vegetation plants with the application of $40 \mathrm{tha}^{-1} \mathrm{AM}+\mathrm{NPK}$. Moreover, the highest yield was reached in the plants in the soil where $40 \mathrm{t} \mathrm{ha}^{-1} \mathrm{AM}+\mathrm{NPK}$ was applied; and an increase of $305 \%$ over the control (7.04 $\mathrm{t} \mathrm{ha}^{-1}$ ) (Figure 2, Duncan's test $\mathrm{P}<0.05$ ). Roe (1998) reported that compost plus fertilizer combinations have been increased efficiency. Togun \& Akanbi (2003) found that the use of compost alone or compost with mineral fertilizer was better than the control. Roe et al (1997) also reported that pepper and cucumber yields were usually higher when compost was combined with mineral fertilizers. Trávník et al (1998) observed an increase in the yield from 47.6 to $83.7 \%$ for various crops fertilized with farmyard manure and NPK compared with the unfertilized crop. Moreover, Ragasits \& Kismanyoky (2000) reported that simultaneous application of NPK and farmyard manure has been shown to increase wheat gluten content and quality. Vogtmann et al (1993) found that compost treatments resulted in lower vegetable yields in the first two years, but there were no different yield results after the third year. In contrast, Eghball et al (2005) showed that residue effects of manure application on crop production and soil properties can last for several years.

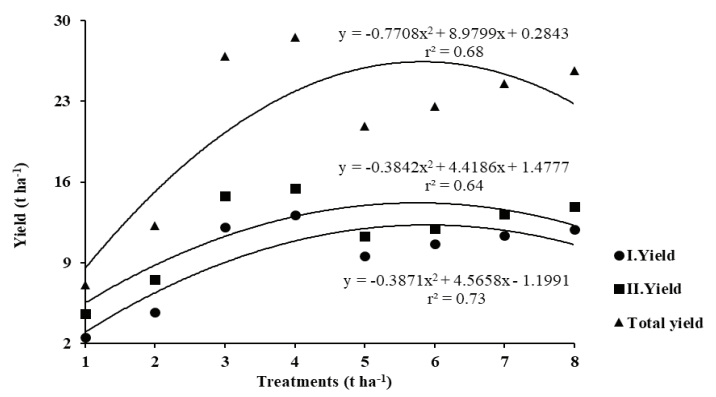

Figure 2- Pepper yield. Treatments; (1), Control; (2), NPK; (3), 40 t ha $^{-1} \mathrm{AM}$; (4), $40 \mathrm{t} \mathrm{ha}^{-1} \mathrm{AM}+$ NPK; (5), 40 t ha $^{-1}$ TR; (6), 40 t ha $^{-1}$ TR + NPK; (7), 80 t ha $^{-1}$ TR; (8), 80 t ha ${ }^{-1}$ TR + NPK. Duncan's test $(P<0.05)$

\section{Conclusions}

The utilization of agricultural wastes derived from animal manure and greenhouse plants combined with or without mineral fertilizer for agronomic purposes is a potential management practices for sustainable agriculture. From the findings, it can be concluded that sandy loam soil amended with animal manure and composted tomato residues resulted in significant increase in pepper yield, total $\mathrm{N}$, available $\mathrm{P}, \mathrm{K}, \mathrm{Ca}, \mathrm{Mg}$, and $\mathrm{Na}$ content of soil. The increase in yield has been mainly owing to the improvement in the nitrogen and phosphorus content of the soil. $40 \mathrm{t} \mathrm{ha}^{-1} \mathrm{AM}+\mathrm{NPK}$ and $80 \mathrm{t}$ $\mathrm{ha}^{-1} \mathrm{TR}+\mathrm{NPK}$ applications gave the best crop yield values and improved soil nutritional quality under the conditions of this experiment. Adding different organic amendments to soil could be useful for various crops, and generally the use of plant residues could be a better option. Furthermore, the quality of used waste is an important parameter in view of agricultural management and crop productivity. Composting of greenhouse wastes promises to be an environmentally friendly alternative that converts the biodegradable wastes into a useful compost material. Composted materials could be a potential 
organic matter source and could also be utilized as a growing medium supplement in greenhouse vegetable productions.

\section{Acknowledgements}

Financial support from the Dumlupinar University Scientific Research Found under grant number 2014/16 is acknowledged.

\section{References}

Agbede T M \& Ojeniyi S O (2009). Tillage and poultry manure effects on soil fertility and sorghum yield in southwestern Nigeria. Soil and Tillage Research 104(1): 74-81

Alluvione F, Fiorentino N, Bertora C, Zavattaro L, Fagnano M, Chiarandà F Q \& Grignani C (2013). Short-term crop and soil response to C-friendly strategies in two contrasting environments. European Journal of Agronomy 45: 114-123

Ayuso M, Pascual J A, Garcia C \& Hernandez T (1996). Evaluation of urban wastes for agricultural use. Soil Science and Plant Nutrition 42(1): 105-111

Batlle-Bayer L, Batjes N H \& Bindraban P S (2010). Changes in organic carbon stocks upon land use conversion in the Brazilian Cerrado: A review. Agriculture, Ecosystems and Environment 137(1-2): 47-58

Bouyoucos G J (1962). Hydrometer method improved for making particle size analyses of soils. Agronomy Journal 54: 464-465

Bremner J M (1965). Total nitrogen. In: C A Black (Ed), Methods of Soil Analysis Part II, American Society of Agronomy Inc. Publisher, Madison, Wisconsin, pp. 1149-1178

Bulluck L R, Brosius M, Evanylo G K \& Ristaino J B (2002). Organic and synthetic fertility amendments influence soil microbial, physical and chemical properties on organic and conventional farms. Applied Soil Ecology 19(2): 147-160

Castellanos J Z \& Pratt P F (1981). Mineralisation of manure nitrogen correlation with laboratory indexes. Soil Science Society of America Journal 45(2): 354-357

Cercioglu M, Yagmur B, Kara R S \& Okur B (2017). Agro-endüstriyel kompost ve ahır gübresinin biber (Capsicum annuum L.) yetiştiriciliğinde toprağın bazı kimyasal özellikleri ile verim üzerine etkisi. Ege Universitesi Ziraat Fakultesi Dergisi 54(1): 71-77
Chang J I, Tsai J J \& Wu K H (2006). Composting of vegetable waste. Waste Management and Research 24(4): 354-362

Courtney R G \& Mullen G J (2008). Soil quality and barley growth as influenced by the land application of two compost types. Bioresource Technology 99(8): 2913-2918

Edmeades D C (2003). The long-term effects of manures and fertilisers on soil productivity and quality: A review. Nutrient Cycling in Agroecosystems 66(2): $165-180$

Eghball B, Ginting D \& Gilley J E (2005). Residual effects of manure and compost applications on corn production and soil properties. American Society of Agronomy Journal 96(2): 442-447

IBM Corp. (2017). IBM SPSS statistics for Windows, version 25. Armonk, NY, USA

Kacar B (1994). Bitki ve Toprağın Kimyasal Analizleri III. Toprak Analizleri. Ankara Üniversitesi Ziraat Fakültesi Eğitim Araştırma Ve Geliştirme Vakfı Yayınları: 3, Ankara, Türkiye

Kaplan M, Köseoğlu T, Aksoy T, Pilanalı N \& Sarı M (1995). Batı Akdeniz Bölgesinde serada yetiştirilen domates bitkisinin beslenme durumunun toprak ve yaprak analizleri ile belirlenmesi. Tübitak Projesi. Proje No: TOAG987/DPT-3, Antalya, $72 \mathrm{~s}$

Kelley W T \& Boyhan G (2009). Commercial Pepper Production Handbook. The University of Georgia, Cooperative Extension

Kulcu R (2014). Composting of greenhouse tomato plant residues, wheat straw, and separated dairy manure, and the effect of free air space on the process. Polish Journal of Environmental Studies 23(4): 1341-1346

Lal R (2007). Anthropogenic influences on world soils and implications to global food security. Advances in Agronomy 93: 69-93

Li L J \& Han X Z (2016). Changes of soil properties and carbon fractions after long-term application of organic amendments in Mollisols. Catena 143: 140-144

Lindsay W L \& Norvell W A (1978). Development of a DTPA soil test for zinc, iron, manganese and copper. Soil Science Society of America Journal 42(3): 421-428

Loue' A (1968). Diagnostic Petiolaire de Prospection. Edutes Sur la Nutrition et la Fertilisation Potassiques de la Vigne. Societe Commerciale des Potasses d'Alsace Services Agromiques, pp. 31-41 
Nelson D W \& Sommer L E (1982). Total carbon, organic carbon and organic matter. In: A L Page, R H Miller \& D R Keeney (Eds), Methods of Soil Analysis Part II: Chemical and Microbiological Properties, American Society of Agronomy, Madison, WI, pp. 539-579

Olsen S R, Cole C V, Watanabe F S \& Dean L A (1954). Estimation of Available Phosphorus in Soils by Extracting with Sodium Bicarbonate. USDA Circ. 939, US Government Printing Office, Washington, D.C

Pan Z, Andrade D, Segal M, Wimberley J, McKinney N \& Takle E (2010). Uncertainty in future soil carbon trends at a central U.S. site under an ensemble of GCM scenario climates. Ecological Modelling 221(5): 876-881

Peigne J, Ball, B C, Roger-Estrade J \& David C (2007). Is conservation tillage suitable for organic farming? A review. Soil Use Management 23(2): 129-144

Pratt P F (1965). Potassium. In: C A Black (Ed), Methods of Soil Analysis Part II: Chemical and Microbiological Properties, Madison, Wisconsin: ASA, pp. 1023-1031

Ragasits I \& Kismanyoky T (2000). Effects of organic and inorganic fertilization on wheat quality. Novenytermeles 49(5): 527-532

Roe N E (1998). Compost utilization for vegetable and fruit crops. HortScience 33(6): 934-937

Roe N E, Stoffella P J \& Graetz D (1997). Composts from various municipal solid waste feedstocks affect vegetable crops. II. Growth, yields and fruit quality. Journal of American Society of Horticulture Science 122(3): 433-437

Ros M, Hernandez M T \& Garcia C (2003). Soil microbial activity after restoration of a semiarid soil by organic amendments. Soil Biology and Biochemistry 35(3): 463-469

Saltalı K, Brohi A R \& Bilgili A V (2000). The effect of tobacco waste on the soil characteristics and plant nutrient contents of alkaline soils. In: Proceedings of International Symposium on Desertification, 13-17 June, Konya, Turkey, pp. 531-534

Schlichting E \& Blume E (1966). Bodenkundliches practikum. Hamburg and Berlin: Verlag Paul Parey

Schoebitz M \& Vidal G (2016). Microbial consortium and pig slurry to improve chemical properties of degraded soil and nutrient plant uptake. Journal of Soil Science and Plant Nutrition 16(1): 226-236

Shang Q, Ling N, Feng X, Yang X, Wu P, Zou J, Shen Q \& Guo S (2014). Soil fertility and its significance to crop productivity and sustainability in typical agroecosystem: a summary of long-term fertilizer experiments in China. Plant and Soil 381(1-2): 13-23

Sillanpää M (1990). Micronutrient Assessment at Country Level: An International Study. FAO Soils Bulletin 63. Food and Agriculture Organization of the United Nations, Rome, Italy

Siwik-Ziomek A \& Lemanowicz J (2014). The content of carbon, nitrogen, phosphorus and sulphur in soil against the activity of selected hydrolases as affected by crop rotation and fertilisation. ZemdirbysteAgriculture 101(4): 367-372

Sumner M E \& Miller W P (1996). Cation exchange capacity and exchange cations. In: D L Sparks (Ed), Methods of Soil Analysis Part III: Chemical Methods, American Society of Agronomy, Madison, WI, pp. 1201-1229

Tejeda M, Garcia C, Gonzalez J L \& Hernandez M T (2006). Organic amendment based on fresh and composted beet vinasse: Influence on physical, chemical and biological properties and wheat yield. Soil Science Society of America Journal 70(3): 900-908

Togun A O \& Akanbi W B (2003). Comparative effectiveness of organic-based fertilizer to mineral fertilizer on tomato growth and fruit yield. Compost Science and Utilization 11(4): 337-442

Trávník K, Vaněk V, Němeček R \& Petrásek K (1998). The effect of long-term fertilizing and liming on soil pH and crop yields. Rostlinna Vyroba 44(10): 471-476

TUIK (2017). Turkish Statistical Institute data basisagriculture, http://www.tuik.gov.tr (Date of access: 01.02.2017)

Vogtmann H, Matthies K, Kehres B \& Meier-Ploeger A (1993). Enhanced food quality: effects of composts on the quality of plant foods. Compost Science \& Utilization 1(1): 82-100

Walker R F (2003). Comparison of organic and chemical soil amendments used in the reforestation of a harsh Sierra Nevada site. Restoration Ecology 11(4): 446-474

Wang C M, Changa C M, Watson M E, Dick W A, Chen Y \& Hoitink H A J (2004). Maturity indices of composted dairy and pig manures. Soil Biology and Biochemistry 36(5): 767-776

Zhang H M, Yang X Y, He X H, Xu M G, Huang S M, Liu H \& Wang B R (2011). Effect of long-term potassium fertilization on crop yield and potassium efficiency and balance under wheat-maize rotation in China. Pedosphere 21(2): 154-163 